\title{
PENGEMBANGAN BAHAN AJAR FISIKA BERBASIS PBL (PROBLEM BASED LEARNING) PADA POKOK BAHASAN LISTRIK DINAMIS UNTUK SMA/MA KELAS X
}

\author{
${ }^{1}$ Intan Kusuma Wardani, ${ }^{2}$ Maulidin, ${ }^{3}$ Erna Fitriatun \\ IKIP MATARAM \\ intankusumawardani@ikipmataram.ac.id
}

\begin{abstract}
Abstrak
Tujuan penelitian adalah untuk mendeskripsikan kelayakan bahan ajar fisika berbasis PBL (Problem Based Learning) pada pokok bahasan Listrik Dinamis. Penelitian ini merupakan penelitian pengembangan yang menggunakan lima langkah awal metode Borg dan Gall, yaitu penelitian dan pengumpulan data, perencanaan, pengembangan draf produk, uji coba, dan revisi hasil uji coba. Kelayakan diukur dengan menggunakan uji validasi oleh tim ahli materi (dosen Fisika) dan pengguna bahan ajar (guru Fisika Madrasah Aliyah NW Kota Raja Kec. Sikur Lombok Timur).dan uji keterbacaan oleh siswa. Hasil validasi dari penelitian ini menunjukkan bahwa bahan ajar fisika berbasis PBL (Problem Based Learning) dan penanaman nilai-nilai kewirausahaan pada pokok bahasan listrik dinamis mem-peroleh nilai rata-rata 3,57 yang berarti layak. Bahan ajar ini perlu dilakukan per-baikan berdasarkan saran dan kritik dari tim validator. Bahan ajar fisika ini belum dapat digunakan untuk pembelajaran di kelas. Berdasarkan hasil penelitian ini disarankan untuk melakukan penelitian pengembangan lebih lanjut terhadap bahan ajar fisika tersebut dengan melakukan kajian eksperimen dan uji coba yang lebih luas, sehingga di-peroleh bahan ajar fisika berbasis PBL (Problem Based Learning) dan penanaman nilai-nilai kewirausahaan pada pokok bahasan listrik dinamis yang teruji validitasnya secara empiris dan siap digunakan.
\end{abstract}

Kata Kunci: Bahan Ajar, Fisika, PBL, Listrik

\section{PENDAHULUAN}

Sumber daya manusia yang memiliki kemampuan berpikir kritis dan kreatif diperlukan untuk menghadapi tantangan pembangunan di masa depan. Perkembangan zaman yang semakin cepat dan perkembangan teknologi yang semakin canggih berdampak pada perubahan-perubahan di berbagai bidang. Untuk melangsungkan pembangunan dengan tantangan perubahan semacam ini, diperlukan sumber daya manusia yang memiliki kemampuan berpikir kritis dan kreatif. Mengingat pentingnya hal ini, institusi pendidikan perlu membekali peserta didik dengan kemampuan berpikir kritis dan kreatif.

Pentingnya penanaman kemampuan berpikir kritis dan kreatif telah diamanatkan dalam dokumen berkatian dengan pendidikan. Menurut Peraturan Mendiknas No. 23 tahun 2006 tentang Standar Kompetensi Kelulusan untuk Satuan Pendidikan Dasar dan Menengah, Peraturan Mendiknas No. 19 Tahun 2006, Peraturan Mendiknas No. 17 Tahun 2006.
Namun demikian, praktik pendidikan menunjukkan bahwa pengem-bangan kemampuan berpikir kritis dan kreatif belum dilaksanakan dengan baik. Kurangnya penanaman berpikir kritis dan kreatif juga tampak dalam bahan ajar yang digunakan oleh peserta didik. Kenyataannya di lapangan menunjukkan bahwa bahan ajar yang beredar masih belum memperlihatkan kualitas dalam mengembangkan kemampuan berpikir peserta didik secara kritis dan kreatif. Oleh karena itu, dibutuhkan bahan ajar yang dapat mengembangkan daya pikir kritis dan kreatif peserta didik dan dapat menanamkan nilainilai pada peserta didik sehingga penelitian ini sangat penting untuk dilakukan.

Upaya mendorong pengembangan kemampuan berpikir kritif dan kreatif peserta didik, maka salah satu model pembelajaran yang tepat adalah Pem-belajaran Kooperatif tipe PBL (Problem based Learning). Pembelajaran ini meru-pakan pembelajaran yang didasarkan masalah dimana merupakan peristiwa-peristiwa yang berada di sekitar 
lingkungan peserta didik. Hal ini memungkinkan dengan materi bahan ajar yang didasarkan masalah yang ada di lingkungan peserta didik, dapat membuat peserta didik lebih tertarik dan lebih antusias dalam belajar. Pengembangan kemampuan berpikir kritis dan kreatif juga didukung oleh kuri-kulum yang berlaku saat ini yaitu Kurikulum Tingkat Satuan Pendidikan (KTSP). Kurikulum ini lebih mementingkan keaktifan peserta didik dalam belajar, di mana kurikulum ini merupakan kurikulum operasional yang disusun oleh dan dilaksanakan di masing-masing satuan pendidikan yang terdiri dari tujuan pendidikan tingkat satuan pendidikan, struktur, dan muatan kurikulum tingkat satuan pendi-dikan, kalender pendidikan, dan silabus. Berdasarkan hal di atas, kuri-kulum ini sangat cocok dengan model pembelajaran PBL (Problem Based Learning) karena cenderung membuat peserta didik untuk aktif dalam memahami materi, mene-mukan masalah, dan menyelesaikan masalah yang dapat mendukung pengem-bangan kemampuan berpikir kritis dan kreatif peserta didik.

\section{METODE PENELITIAN}

Pada penelitian ini, metode yang digunakan adalah metode penelitian dan pengembangan menurut Brog dan Gall merujuk dari Sukmadinata (2008:145). Prosedur penelitian yang dilakukan ada 5 tahap yakni (1) tahap penelitian dan pengumpulan data, dimana dilakukan survei tempat dan permasalahan yang ada dan dikumpulkan data melalui wawancara dan angket, (2) tahap perencanaan, hasil data survei digunakan sebagai pedoman untuk merancang solusi yang tepat, (3) tahap pengembangan draf produk, setelah selesai direncanakan maka dibuat suatu produk yang didesain berdasarkan perencanaan yang ada, (4) tahap uji coba, produk yang sudah jadi diuji cobakan melalui tim penilai dan siswa.

Data yang diperoleh adalah data kuantitatif yang berupa hasil nilai dari validator melalui angket dan data kualitatif yang berupa tanggapa, saran, dan kritik dari tim validator dan uji keterbacaan dari siswa. Data hasil penilaian tim ahli dihitung dengan teknis analisa rata-rata (Arikunto, 2006:216), sedangkan data hasil berupa tanggapan, saran, dan kritik oleh tim ahli serta hasil keterbacaan oleh siswa untuk perbaikan.

Desain uji coba adalah validasi isi bukan validasi empirik. Validasi isi dilakukan oleh tim ahli (Dosen Fisika Hamzanwadi Pancor dan 1 Guru Fisika (guru Fisika Madrasah Aliyah NW Kota Raja Kec. Sikur Lombok Timur)) dan uji keterbacaan bahan ajar oleh siswa. Instrumen penelitian yang digunakan berupa lembar validasi untuk tim ahli dan lembar angket untuk siswa. Penelitian ini dilakukan di Madrasah Aliyah NW Kotaraja Lombok Timur pada bulan September Tahun 2019.

\section{HASIL PENELITIAN}

Penelitian yang sudah dilakukan berdasarkan langkah-langkah menurut Brog dan Gall merujuk dari Sukmadinata (2008:145) diperoleh data hasil penilaian terhadap bahan ajar fisika seperti Tabel 4.1.

\begin{tabular}{|c|c|c|c|c|}
\hline \multirow{2}{*}{ 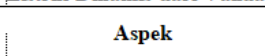 } & \multicolumn{3}{|c|}{ Validator } & \multirow[b]{2}{*}{ Rata-Rata } \\
\hline & Vl & V2 & V3 & \\
\hline Halaman muka (cover) & 3.8 & 3.6 & 2.8 & 3.4 \\
\hline Kata Pengantar & 2.5 & 3.25 & 2.75 & 2.83 \\
\hline Daftarisi & 3.67 & 4 & 4 & 3.89 \\
\hline $\begin{array}{l}\text { Petunjuk Penggunaan Bahan } \\
\text { Ajar }\end{array}$ & 3 & 3.25 & 4 & 3.42 \\
\hline Pendahuluan & 3 & 3.75 & 3.75 & 3.5 \\
\hline Kompetensi dasar & 4 & 4 & 3.5 & 3.83 \\
\hline Indikator & 3.8 & 3.6 & 3.6 & 3.67 \\
\hline Bentuk bahan ajar & 3 & 3.75 & 3.75 & 3.5 \\
\hline Materi & 3.3 & 3.6 & 3.6 & 3.5 \\
\hline Lembar kerja siswa & 3.38 & 3.88 & 4 & 3.75 \\
\hline Ilustrasi / gambar & 3.5 & 4 & 3.83 & 3.78 \\
\hline Rangkuman & 3.67 & 3.3 & 3.5 & 3.5 \\
\hline Soal evaluasi & 2.75 & 3.25 & 3.75 & 3.25 \\
\hline Proyek & 3 & 3.67 & 3.67 & 3.44 \\
\hline Kunci jawaban & 4 & 4 & 3.4 & 3.8 \\
\hline Glosarium & 3.3 & 3.67 & 4 & 3.67 \\
\hline Daftar pustaka & 3.5 & 3.5 & 4 & 3.67 \\
\hline Umpan balik & 3.3 & 4 & 4 & 3.78 \\
\hline
\end{tabular}

Selain memberikan penilaian berupa angka, validator juga memberikan penilaian berupa tanggapan, saran dan kritik terhadap Bahan Ajar Fisika yang disajikan dalam Tabel 4.2. 


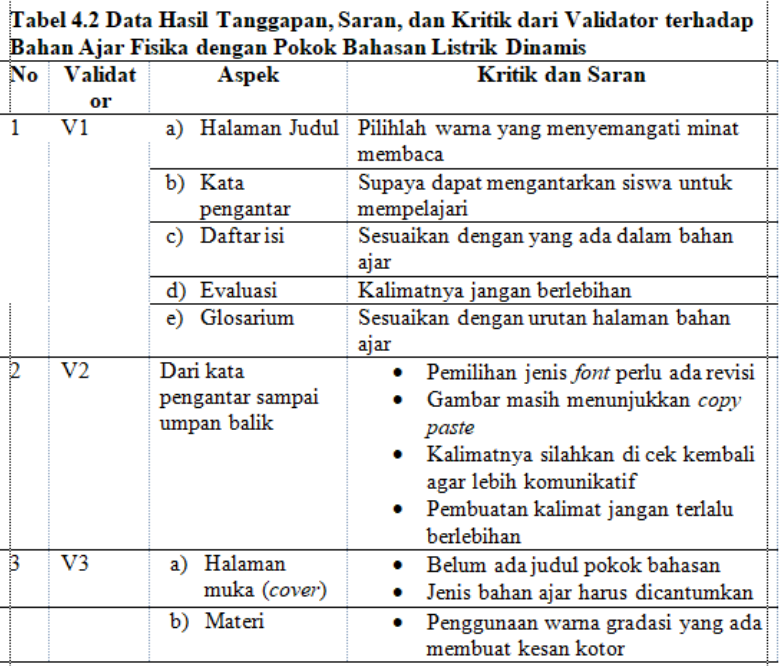

Selain hasil uji coba dari penilaian validator juga dari uji keterbacaan siswa. Tabel 4.3 merupakan data hasil uji keterbacaan siswa berupa kata-kata yang sulit sedangkan untuk data hasil uji keterbacaan siswa berupa kalimat yang tidak dipahami tidak ada. Berdasarkan data hasil uji keterbacaan siswa, maka kata-kata sulit tersebut akan menjadi rujukan pada glosarium.

Tabel 4.3 Hasil Uji Keterbacaan Siswa Kelas X Madrasah Aliyah NW Kotaraja Lombok Timur terhadap Bahan Ajar Fisika Berupa Kata-Kata yang Sulit.

\begin{tabular}{|c|c|c|}
\hline $\mathrm{N}_{0}$ & Kata Sulit & Hal Prototipe \\
\hline l & Equivalensi & 38 \\
\hline & Transformasi & 38 \\
\hline
\end{tabular}

Penjelasan data hasil validasi Pengembangan Bahan Ajar Fisika dengan Pokok Bahasan Listrik Dinamis untuk siswa di Madrasah Aliyah NW Kotaraja Lombok Timur kelas $\mathrm{X}$ semester genap adalah dilakukan penilaian terhadap aspek-aspek yang ada di bahan ajar tersebut. Setiap aspek dinilai berdasarkan kriteria penilaian pada Tabel 3.1 dan secara umum hasil validasi untuk masing-masing aspek dapat dilihat pada Tabel 4.4.

\begin{tabular}{|l|c|c|}
\hline \multicolumn{1}{|c|}{ Tabel 4.4 Hasil Rata-Rata Setiap Aspek pada Validasi Bahan Ajar } \\
\hline \multicolumn{1}{|c|}{ Aspek } & Rata-Rata & Kriteria \\
\hline Halaman muka (cover) & 3.4 & Layak \\
\hline Kata pengantar & 2.83 & Cukup layak \\
\hline Daftar isi & 3.89 & Layak \\
\hline Petunjuk penggunaan bahan ajar & 3.42 & Layak \\
\hline Pendahuluan materi & 3.5 & Layak \\
\hline Kompetensi dasar & 3.83 & Layak \\
\hline Indikator hasil pencapaian & 3.67 & Layak \\
\hline Bentuk bahan ajar & 3.5 & Layak \\
\hline Materi & 3.5 & Layak \\
\hline Lembar kerja siswa & 3.75 & Layak \\
\hline Ilustrasi / gambar & 3.78 & Layak \\
\hline Rangkuman & 3.5 & Layak \\
\hline Evaluasi & 3.25 & Cukup Layak \\
\hline Proyek & 3.44 & Layak \\
\hline Daftar pustaka & 3.8 & Layak \\
\hline Glosarium & 3.67 & Layak \\
\hline Kunci jawaban & 3.67 & Layak \\
\hline Umpan balik & 3.78 & Layak \\
\hline
\end{tabular}

\section{PEMBAHASAN}

Analisis data pada Bahan Ajar Fisika dengan Pokok Bahasan Listrik Dinamis didasarkan pada hasil analisis rata-rata angket skala Likert oleh dosen Fisika Hamzanwadi Pancor Selong Lombok Timur dan 1 guru Fisika Madrasah Aliyah NW Kotaraja Lombok Timur. Berdasarkan data hasil validasi secara keseluruhan diperoleh skor rata-rata Bahan Ajar Fisika adalah sebesar 3,57, sehingga memenuhi kategori layak. Dari data hasil validasi tersebut, dapat disimpulkan bahwa Pengembangan Bahan Ajar Fisika dengan Pokok Bahasan Listrik Dinamis untuk siswa MA Kelas $X$ semester genap tidak memerlukan perombakan yang signifikan. Namun, berdasarkan saran, tanggapan, dan kritik dari validator menunjukkan bahwa terdapat beberapa bagian dari bahan ajar fisika perlu diperbaiki.

Tabel 4.5 Revisi Bahan Ajar Fisika Berdasarkan Tanggapan, Saran dan Kritik dari Validator terhadap Bahan Ajar Fisika 


\begin{tabular}{|c|c|c|c|}
\hline No & Aspek & Kritik dan Saran & Hasil Revisi \\
\hline \multirow[t]{5}{*}{1} & $\begin{array}{l}\text { a) Halaman } \\
\text { Judul }\end{array}$ & $\begin{array}{l}\text { Pilihlah warna yang } \\
\text { menyemangati minat } \\
\text { membaca }\end{array}$ & $\begin{array}{l}\text { Pada cover sudah } \\
\text { menggunakan warna } \\
\text { yangmenarik minst } \\
\text { untuk membaca }\end{array}$ \\
\hline & $\begin{array}{l}\text { b) Kata } \\
\text { pengantar }\end{array}$ & $\begin{array}{l}\text { Supaya dapat mengantarkan } \\
\text { siswa untuk mempelajari }\end{array}$ & $\begin{array}{l}\text { Kalimat pada kata } \\
\text { pengantar sudah diubah } \\
\text { agar dapat mengantarkan } \\
\text { siswa untuk mempelajar: }\end{array}$ \\
\hline & c) Daftar isi & $\begin{array}{l}\text { Sesuaikan dengan yang ada } \\
\text { dalam bahan ajar }\end{array}$ & $\begin{array}{l}\text { Sudah disesuaikan untulk } \\
\text { kata dan halaman pada } \\
\text { bahan ajar }\end{array}$ \\
\hline & d) Evaluasi & Kalimatnya jangan berlebihan & $\begin{array}{l}\text { Kalimat sudah diganti } \\
\text { sesuai ejaan yang benar }\end{array}$ \\
\hline & e) Glosarium & $\begin{array}{l}\text { Sesuaikan dengan urutan } \\
\text { halaman bahan ajar }\end{array}$ & $\begin{array}{l}\text { Sistematika penulis an } \\
\text { sudah diperbsiki }\end{array}$ \\
\hline 2 & $\begin{array}{l}\text { Dari kata } \\
\text { pengantar } \\
\text { sampai umpan } \\
\text { balik }\end{array}$ & $\begin{array}{l}\text { - Pemilihan jenis font perbu } \\
\text { ada revisi } \\
\text { - Gambar masih } \\
\text { menunjukkan copy paste } \\
\text { - Kalimatnya silahkan di } \\
\text { cek kembali agar lebih } \\
\text { komunikatif } \\
\text { - Pembuatan kalimat } \\
\text { jangan terlalu berlebihan }\end{array}$ & 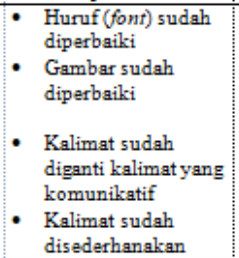 \\
\hline B & $\begin{array}{l}\text { a) Halaman } \\
\text { muka (cover) }\end{array}$ & $\begin{array}{l}\text { - Belum ada judul pokok } \\
\text { bahasan } \\
\text { - Jenis bahan ajar harus } \\
\text { dicantumkan }\end{array}$ & $\begin{array}{l}\text { - Pada cover sudah } \\
\text { diberikan judul poko } \\
\text { bahasan } \\
\text { - Sudah dicantumkan } \\
\text { untuk jenis bahan ajas }\end{array}$ \\
\hline & b) Materi & $\begin{array}{l}\text { Penggunaan warna } \\
\text { gradasi yang ada } \\
\text { membuat kesan kotor }\end{array}$ & $\begin{array}{l}\text { - Sudah diberikan } \\
\text { warna yang sesuai } \\
\text { dan tidak telalu } \\
\text { berlebihan }\end{array}$ \\
\hline
\end{tabular}

Data hasil uji keterbacaan bahan ajar diperoleh dari sepuluh siswa kelas $\mathrm{X}$ Madrasah Aliyah NW Kotaraja Lombok Timur yang memiliki kemampuan intelektual berbeda dengan rincian 3 siswa berkemampuan tinggi, 4 siswa berkemampuan sedang dan 3 siswa berkemampuan rendah. Tabel 4.6 merupakan data hasil uji keterbacaan siswa berupa katakata yang sulit dimengerti dan dimasukkan dalam gloasarium.

Tabel 4.6 Hasil Revisi Kata yang Sulit dari Uji keterbacaan siswa Kelas XMadrasah Aliyah NW Kotaraja Lombok Timur terhadap Bahan Ajar Fisika

\begin{tabular}{|c|c|c|c|}
\hline $\mathrm{N}_{0}$ & Kata Sulit & Hal & Hasil revisi \\
\hline 1 & Equivalensi & 38 & tenemahan diletadkan dibagian glosarium \\
\hline 2 & Tranformasi & 38 & tememahan diletatkkan dibagian glosarium \\
\hline
\end{tabular}

\section{KESIMPULAN}

Hasil pengembangan berupa Bahan Ajar Fisika berbasis PBL (Problem Based Learning) dan penanaman nilai-nilai Kewirausahaan pada pokok bahasan Listrik Dinamis. Bahan ajar pembelajaran digunakan untuk siswa SMA/MA kelas $\mathrm{X}$ semester genap dan dikembangkan setelah direvisi sesuai dengan hasil uji kelayakan oleh validator dan uji keterbacaan oleh siswa. Data hasil validasi oleh validator diolah dengan menggunakan teknik analisis nilai rata-rata berdasarkan pendapat Arikunto (2002:216). Berdasarkan data hasil validasi oleh tim ahli dan pengguna, didapatkan nilai rata-rata sebesar 3,57, sehingga dapat dikategorikan layak.

Bahan Ajar Fisika dengan Pokok Bahasan Listrik Dinamis yang dikembangkan memiliki beberapa karakteristik yaitu (a) disajikan dengan Pokok Baha-san Listrik Dinamis yang merupakan materi yang lingkupnya sangat dekat dengan lingkungan siswa, (b) Bahan Ajar Fisika dengan Pokok Bahasan Listrik Dinamis yang dikembangkan berdasarkanPBL (Problem Based Learning) sehingga lebih bermakna, karena siswa akan memahami konsep-konsep yang dipelajari melalui pengalaman langsung dan menghubungkannya dengan peristiwa yang ada di sekitar mereka serta siswa dapat mengembangkan kemampuan berpikir kritis dan kreatif, (c) Bahan Ajar Fisika dengan Pokok Bahasan Listrik Dinamis yang dikembangkan juga dilengkapi kegiatan siswa dengan tujuan memberikan kesem-patan pada siswa agar aktif bekerja dengan baik secara mandiri maupun kelompok untuk melakukan percobaan, melakukan pengamatan, mengumpulkan data, dan mengolah data, (d) soal-soal evaluasi merupakan soal Fisika khususnya listrik dinamis, (e) disertai kegiatan proyek yang memungkinkan siswa dapat mengem-bangkan daya pikir kritis dan kreatif, dan keterampilan. Selain itu, merupakan perwujudan untuk menanamkan nilai-nilai kewirausahaan kepada siswa meliputi rasa ingin tahu, tanggungjawab, kerja sama, inovatif, kreatif, dan etos kerja dan (f) Bahan Ajar Fisika dengan Pokok Bahasan Listrik Dinamis yang dikembangkan dilengkapi dengan kegiatan berupa rubrik sebagai bentuk penanaman nilai-nilai kewirausahaan yang baik dimiliki oleh siswa.

\section{SARAN}

Berdasarkan hasil penelitian di atas, maka peneliti memiliki saran kepada:

1. Bagi Guru

Hasil pengembangan produk dapat dijadikan bahan sebagai hasil karya yang dinilai untuk menambah angka kredit keperluan kenaikan pangkat. Namun, 
produk ini perlu dilakukan pengkajian lebih lanjut dan uji coba lapangan.

2. Bagi Siswa

Hasil pengembangan produk ini dapat digunakan siswa untuk sumber belajar dalam kegiatan pembelajaran tetapi perlu dikaji dan diuji coba ebih lanjut hingga siap digunakan.

3. Bagi Lembaga Pendidikan

Apabila lembaga pendidikan ingin menerbitkan atau mempublikasikan produk ini, maka perlu menaati peraturan dalam Permendiknas No. 22 Tahun 2006 tentang Standar Isi.

4. Bagi Peneliti Lain

Hasil penelitian dapat dijadikan sebagai referensi untuk melakukan penelitian yang lainnya. Selain itu, produk ini juga dapat dikembangkan lagi menjadi lebih baik.

\section{DAFTAR RUJUKAN}

Arikunto, Suharsimi. 2006. Prosedur Penelitian suatu Pendekatan Praktek. Jakarta: PT Rineka Cipta

Depdiknas.2006.Pedoman memilih dan menyusun bahan ajar.Jakarta:

Direktorat Sekolah Menengah Pertama

Ennis. H, Robert. 1996. Critical Thinking. USA: Prentice-hall inc

Hassoubah, Izhab Zaleha. 2004. Developing Creatif and Critical Thinking Skill (Cara Berpikir Kreatif dan Kritis). Bandung: Nuansa

Ibrahim, dkk. 2000. Model-model Pembelajaran. Jakarta: Rineka Cipta

Karhami, S.K.A. 1998. Panduan Pembelajaran Fisika SLTP. Jakarta: Departemen Pendidikan dan Kebudayaan

Kurniawan, Eri. 2002. Pembudayaan keterampilan berpikir kritis Di perguruan tinggi Melalui cognitive coaching. Makalah. Bandung: Universitas Pendidikan Indonesia

Mendiknas. 2006. Peraturan Menteri Pendidikan Nasional No. 17 tentang Pengelolaan dan Pelaksanaan Pendidikan. Jakarta: Mendiknas RI

Mendiknas. 2006. Peraturan Menteri Pendidikan Nasional No. 19 tentang
Standar Nasional Pendidikan. Jakarta: Mendiknas RI

Mendiknas. 2006. Peraturan Menteri Pendidikan Nasional No. 23 tentang Standar Kompetensi Kelulusan. Jakarta: Mendiknas RI

Nasution. 2001. Metode Pemecahan Masalah. Bandung: PT Remaja Rosdakarya

Nurhadi. 2004. Problem Based Learning. Jakarta: Rineka Cipta

Salamah, Umi Nur. 2006. Meningkatkan Kemampuan Berpikir Kritis dan Hasil Belajar Siswa Pada Pokok Materi Kelarutan dan Hasil Kali Kelarutan dengan Pendekatan Hipotesis Deduktif. Skripsi. Semarang: FMIPA Universitas Negeri Semarang

Saputra, Fendi. Kemahiran berpikir secara kritis dan kreatif, (online), (http;//www.mahirkbkk.tipod.com), diakses 20 Mei 2010, jam 20:22

Sudjana, Nana dan Ahmad Rivai. 2003. Teknologi Pengajaran. Bandung: Sinar Baru Algesindo

Sudrajat, Ahmad. 2008. Rencana Pengembangan Sekolah Pendidikan Sepanjang Hayat (I). Pengembangan Bahan Ajar, (online), (http://akhmadsudrajat.wordpress.com/ 2008/01/24/pengembangan-bahanajar/), diakses 12 November 2008

Sukmadinata,N.S. 2007. Metode penelitian pendidikan. Bandung: PT Remaja Rosdakarya

Yuliati, Lia. 2008. Model-model Pembelajaran Fisika 'Teori dan Praktek”. Malang: Lembaga Pengembangan Pendidikan dan Pembelajaran UM 